\title{
Laboratory and Ultrasonographic Diagnosis of Mastitis in Buffaloes
}

\author{
Ebtsam E. Z. Kotb*, A. M. Abu Seeda ${ }^{* * *}$ and Mostafa A. \\ Fadel $^{* *}$ \\ *Department of Mastitis and Neonates Diseases, ${ }^{* *}$ Unit of \\ Ultrasonography, Animal Reproduction Research Institute, and \\ *** Department of Surgery, Faculty of Veterinary Medicine, \\ Cairo University, Cairo, Egypt.
}

\begin{abstract}
$7 \mathrm{HE}$ aims of this study are to through light on the importance of ultrasonography as a useful, accurate and relatively quick tool for diagnosis of mastitis in buffaloes and to correlate the laboratory results with ultrasonographic findings in mastitic buffaloes. In the present study, mastitis was diagnosed in 55 lactating buffaloes by clinical findings, California Mastitis Test (CMT), Somatic Cell Count (SCC), microbiological tests and ultrasonography. The results showed that the ultrasonography is a helpful tool in diagnosis of mastitis in buffaloes. All ultrasongraphic and laboratory findings were discussed in correlation to each other.
\end{abstract}

Keywords: Laboratory Diagnosis, Ultrasonography, Buffaloes, Mastitis.

Diseases of the udder and teat especially mastitis are common in buffaloes worldwide. Mastitis is the inflammatory condition of the udder irrespective of the cause. The magnitude of these changes in individual animal varies with the severity and duration of the infection and the causative microorganisms. These microorganisms produce toxins that can directly damage milk-producing tissue of the mammary gland, and the presence of bacteria initiates inflammation within the mammary tissue in an attempt to eliminate the invading microorganisms (Szencziova and Strapak, 2012).

Mastitis is a combination of physical, chemical and microbiological changes in the milk with pathological changes in the glandular tissue of the udder that affects both the quality and quantity of milk. It is considered as a complex disease caused by the interaction of several factors as animals, the environment and microorganisms such bacterial contamination, mycotic infection and sometimes viral infection. These infections may be with one or more of different micro-organisms that affect both mammary epithelial cell and alveolar function followed by impair both the quantity and quality of milk causing high economic losses for the dairy industry and serious hazard for public health (Jai et al., 2005).

California Mastitis Test (CMT) and Somatic cell count (SCC) are useful predictors of intra mammary infection (IMI) depending upon severity of inflammatory response to infection as mastitis increase migration of polymorphneucler cells in tissue injury and stress. Somatic cells are protective 
for the animal body and fight infectious organisms. An elevated SCC in milk has a negative influence on the quality of raw milk (Sharma et al., 2011).

The inflammation contributes to decrease milk production and is primarily responsible for the compositional changes observed in milk from infected quarters as well as increased costs for treatment and early culling of the animals (NMC, 2011).

Infection of the udder usually takes place directly through teat canal however, organisms may get settled in the mammary tissues via blood as in case of tuberculosis mastitis (NMC, 2004).

Ultrasonography could be used as a helpful tool to diagnose pathological alterations in the udder such as inflammation, mucosal lesions, tissue proliferation, foreign bodies, milk stones, congenital changes, hematoma and abscess. Udder and teat scanning can be also performed for diagnosis of milk flow disturbances and different inner anatomical structures of the teat like teat canal length and diameter, teat cistern diameter, and teat wall thickness (Szencziova and Strapak, 2012).

The ultrasound examination of the udder parenchyma is mainly performed using the direct contact method with lower frequency linear probes $(3.5-5 \mathrm{MHz})$ while examination of the teat is most commonly conducted by the water bath technique with a help of a higher frequency linear probe (at least $7.5 \mathrm{MHz}$ ) for good image quality (Szencziova and Strapak, 2012).

Final diagnosis of mastitis in buffaloes depends mainly upon laboratory diagnosis. The most common laboratory diagnosis of mastitis including CMT, SCC and microbiological diagnosis (NMC, 2001).

The majority of published studies about mastitis are related to etiology, control and prevention of mastitis (Seker et al., 2009).

Therefore, the present study was focused to get the benefits of ultarasonographic and laboratory diagnosis to evaluate the alternation of the tissues damage due to mastitis in buffaloes that help in the decision of treatment or culling and replacement in dairy farms.

\section{Material and Methods}

\section{Animals}

The present study was carried out on fifty five dairy buffaloes suffering mastitis in a research farm at Giza governorate, Egypt during the period between January 2012 and January 2013. The affected animals were examined in standing position under sedation with Xlyazine HCL given intramuscularly at a dose of $0.1 \mathrm{mg} / \mathrm{Kg}$ body weight.

Egypt. J. Vet. Sci. Vol. 44 (2013) 


\section{Laboratory Diagnosis}

Following thorough clinical examination by inspection and palpation, California Mastitis Test (CMT), Somatic Cell Count (SCC) and microbiological examination were carried out.

\section{California Mastitis Test (CMT)}

It was applied to milk samples after discarding the first three strips of fore milk to detect clinical and subclinical mastitis according to Schalm and Noorlander (1957).

\section{Somatic Cell Count (SCC)}

Milk samples were collected from all quarters according to (Andrews et al., 2004) for somatic cell counts (SCC) using Bently 150 infrared Milk Analyzer (Soma count, France). Animals were considered with subclinical mastitis when SCC was $250000-500000$ cells $/ \mathrm{ml}$ milk with positive pathogen isolation and considered as clinical mastitis when SCC above 500000 cells/ml milk (Djabri et al., 2002). The samples containing flakes, clots or other unusual aspect were not used for SCC.

\section{Microbiological Examination}

A total of 220 quarter milk samples were aseptically collected during morning milking for cultivation according to the National Mastitis Council (NMC, 1999). Briefly, from each sample, $0.1 \mathrm{ml}$ of milk was plated on blood agar, Mannetol salt agar, Edwer's media, Macconky agar (one plate per buffalo) and incubated for 24- 48 hours at $37^{\circ} \mathrm{C}$. Dextrose Sabaurd agar was used for isolation of mycotic infections at $25^{\circ} \mathrm{C}$ during one week.

A quarter was considered culture-positive, when growth of at least one colony was detected. Bacteria were identified based on colony morphology and Gram-staining. For Gram-positive cocci, catalase test with hydrogen peroxide (3\%) was used to differentiate between catalase-positive staphylococci and catalase-negative cocci. Coagulase test was carried out using sterile rabbit plasma to distinguish Staphylococcus aureus (coagulase-positive) from nonaureus staphylococci, referred to as coagulase-negative staphylococci. Streptococci were subdivided into aesculin-positive cocci and aesculin-negative cocci (Streptococcus agalactiae and other Streptococcus). CAMP-test was used to differentiate $S$. agalactiae from $S$. dysgalactiae. Enterobacteriace were identified as Gram negative bacilli.

Sensitivity test

It was done by using Muller-Hinton agar media and antibiotic sensitivity discs (Oxoid). The types of antibiotic sensitivity discs were selected according to (Carter and Cole, 1990). 


\section{Ultrasonographic Examination}

It was conducted with ECM-Novico, Exagyne (France) device connecting with linear 5-8 MHz transducer according to (Rambabu et al., 2008) and (Szencziovaand Strapak, 2012). Before scanning, the udder and teats were cleaned thoroughly with warm water then ultrasound coupling gel (Ultrasound Gel, jaayveemeditech international, Pondicherry, India) was applied. Both sagittal and transverse planes were applied then the images were recorded on Polaroid paper with a thermal printer. Water bath method was applied to examine the teats by ultrasound according to (Fasulkov et al., 2010). The examined teat was dipped in a polyethylene cup filled with water then the transducer was applied in both vertical and horizontal planes of the outer wall of the polyethylene cup (Fig. 1).

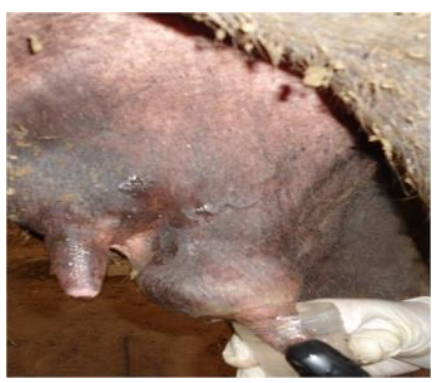

Fig. 1. Ultrasonography Water bath method for teat examination.

\section{Results}

Out of 55 examined buffaloes, 25 (45.5\%) animals suffered clinical mastitis with severe clinical symptoms including: fever and hotness, tenderness, redness and swelling of the udder (Fig. 1).

\section{Laboratory Findings}

California Mastitis Test (CMT)

Out of 55 examined buffaloes, the results of CMT revealed 30 buffaloes suffering subclinical mastitis with different degrees of CMT.

\section{Somatic Cell Count}

Mean cell count from 30 subclinical mastitic buffaloes ranged between 320 000 and $476000 \mathrm{cell} / \mathrm{ml}$ milk.

\section{Microbiological Findings}

Cultures with more than one species of bacterial isolates (mixed infections) were found in most samples (91\%) while single infection was recorded in $9 \%$ of the collected samples (Table 1). The most common isolated pathogens were, $\mathrm{S}$. aureus, environmental bacteria and Candida spp. Candida spp. could be isolated from clinical and subclinical samples with percentages of $33 \%$ and $38.5 \%$ respectively. Culling of buffaloes with mycotic mastitis, multiple udder abscessations or fibrosis was done due to unsuccessful treatment.

Egypt. J. Vet. Sci. Vol. 44 (2013) 
Sensitivity test

Results of the test were collected in Table 1. In the present study, Marbocil and Norfloxacin were the most sensitive antibiotics.

\section{Ultrasonographic Findings}

Ultrasonographic examination gave additional information on the status of the udder and teats. It showed specific findings for some causal agents. In buffaloes with subclinical mastitis, the teat canal and sinus showed irregular contour, the three layers of teat wall couldn't be clearly demarcated and the papillary duct and rosette of Furstenberg showed an overlapped pattern with clarity image of udder parenchyma and gland sinus (Fig. 2a).

The milk alveoli showed anechoic fluid with suspended hypoechoic dots before milking (Fig. 2b). After milking, the echogenicity of milk alveoli increased (Fig. 2c).

TABLE 1. Results of culture and sensitivity tests in clinical and subclinical mastitis in the examined buffaloes.

\begin{tabular}{|c|c|c|c|}
\hline \multirow{8}{*}{$\begin{array}{l}\text { Clinical } \\
\text { Mastitis }\end{array}$} & Bacterial isolates & $\%$ & Sensitivity test \\
\hline & $\begin{array}{c}\text { Coagulase -ve Staph }+ \\
\text { Coliform }\end{array}$ & 38 & $\begin{array}{l}\text { Marbocil, Gentamycin, } \\
\text { Norfoxacin and Ciprofloxacin }\end{array}$ \\
\hline & Strept spp. + Coliform & 22 & $\begin{array}{l}\text { Amoxicillin, Gentamycin and } \\
\text { Cholamphincol }\end{array}$ \\
\hline & S. aureus + Strep.spp & $16 \%$ & $\begin{array}{c}\text { Marbocil , Norfoxacin and } \\
\text { Ciprofloxacin }\end{array}$ \\
\hline & $\begin{array}{l}\text { C. pyogen }+ \text { Strep.spp }+ \\
\text { Coliform }\end{array}$ & $15 \%$ & Marbocil, Gentamycin \\
\hline & S. aureus & $8 \%$ & Marbocil and Norfoxacin \\
\hline & C. pyogen & $1 \%$ & Gentamycin \\
\hline & Total & 100 & \\
\hline \multirow[t]{3}{*}{$\begin{array}{l}\text { Subclinical } \\
\text { Mastitis }\end{array}$} & S. aureus+ Strep.spp & $20 \%$ & $\begin{array}{c}\text { Marbocil, Norfoxacin and } \\
\text { Ciprofloxacin }\end{array}$ \\
\hline & $\begin{array}{c}\text { Coagulase negative Staph+ } \\
\text { Strep.spp }+ \text { Coliform }\end{array}$ & $80 \%$ & $\begin{array}{l}\text { Amoxicillin, Gentamycin and } \\
\text { Cholamphincol }\end{array}$ \\
\hline & Total & \multicolumn{2}{|r|}{ ( } \\
\hline
\end{tabular}
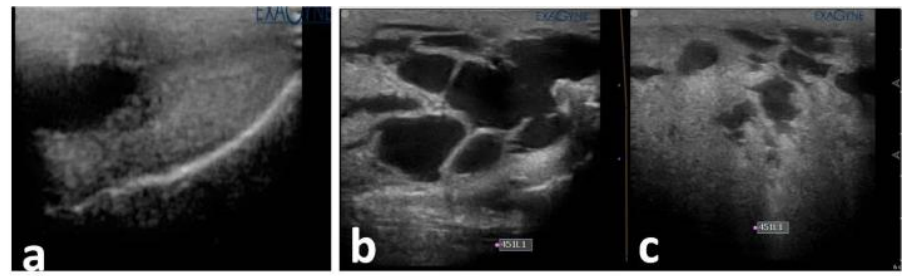

Fig. 2. Showing changes in the udder with subclinical mastitis before and after milking. 
In clinical mastitis, the affected buffaloes showed various ultrasonographic images according to the causative agents. Ultrasonographically, the teat wall was thick and lost its threefold layered appearance, complete obstruction of teat canal and disappearance of rosette of Furstenberg (Fig. 3a). The teat cistern had irregular lining and filled with homogenous hypoechoic milk (Fig. 3b). Milk alveoli in buffaloes suffered clinical mastitis caused by pyogenic bacteria, appeared as anechoic cavities filled with homogenous hypoechoic fluid (Fig. 3c). In case of clinical mastitis caused by Staph.aureus mixed with Candid spp., the milk alveoli had hypoechoic fluid with suspended hyperechoic flakes (Fig. 3d).

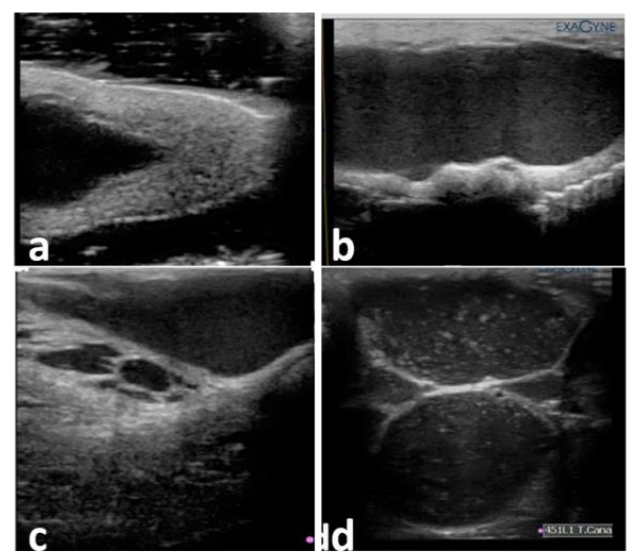

Fig. 3 a. Showing changes of the teat and teat cistern in clinical mastitis.

b. Milk alveoli in clinical mastitis.

c. Showing alveoli in case of pyogenic clinical mastitis.

d. Showing alveoli in case of clinical mastitis caused by $S$. aureus mixed with Candid spp.

Several buffaloes with clinical mastitis developed multiple parenchymatous abscesses (Fig. 4a). All of these buffaloes were infected with either $C$. pyogen and / or Staph. aureus. Ultrasound examination revealed complete obstruction of the teat canal and cistern with hyperechoic mass (Fig. 4b) and the udder parenchyma showed multiple abscesses filled with hyperechoiccaseated pus and surrounded by hyperechoic thick capsules (Fig. 4c). The parenchymatous abscesses caused by Staph. aureus were less echogenic than that caused by $C$. pyogen (Fig. 4d). 


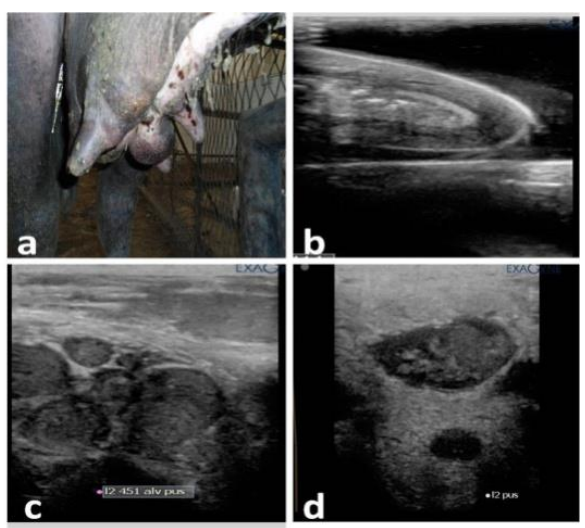

Fig. 4 a. showing multiple parenchymatous abscesses in affected buff aloe.

b. revealed complete obstruction of the teat canal and cistern with hypeechoic mass.

c. showing that The parenchymatous abscesses caused by $S$. aureus were less echogenic than that caused by the C.pyogen a.

d. the udder parenchyma showed multiple abscesses filled with hyperechoic caseated pus and surrounded by hyperechoic thick capsules in case of C.pyogen infection.

Udder atrophy and fibrosis was recorded in four quarters of three mastitic buffaloes (Fig. 5a) Ultrasonographically, the affected teat showed complete disappearance of teat canal and cistern and diffuse hyperechoic small cordial echoes were present (Fig. 5b) The affected udder parenchyma showed complete replacement of the milk alveoli with hyperechoic fibrous tissue (Fig. 5c) Ultrasonography of the other normal quarters showed homogenous and hyperechoic glandular tissue with anechoic milk alveoli.

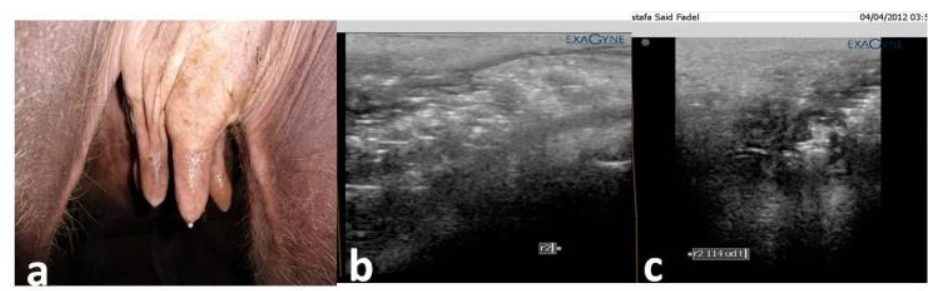

Fig. 5. showing Udder atrophy and fibrosis 


\section{Discussion}

Mastitis makes up negative economic effect and may be lead to transmission of some zoonotic diseases through consumptions of infected low quality milk and milk products.

Mammary quarters infected by major pathogens showed SCC scores greater than those infected by minor pathogens. This is in agreement with the results of (Hoquem et al., 2004, Santos et al., 2004 ,Gungor et al., 2005 and Riekerink et al., 2007). According to (Reneau, 1986) this variation is associated with differences in the magnitude of cellular response and duration of intra mammary infection.

In the present study, some contagious micro-organisms were isolated from mastitic buffaloes as S.aureus and C. pyogen either alone or mixed with some environmental micro-organisms which indicate bad hygiene. These results were in agreement with that recorded by (Karyak et al., 2011).

Isolation of Candida spp. from clinical and subclinical mastitis with high incidence indicates its importance as a causative agent of mastitis in buffaloes and further studies are required to study its prevention and treatment.

Ultrasonography is a helpful tool to diagnose pathologic alterations of the udder such as inflammation, mucosal lesions, hematoma, and abscess. In addition, ultrasonography of the teat allows the localization and demarcation of the extent of pathologic changes that help in the decision of treatment or culling of affected animals in dairy farms (Franz et al., 2009, Fasulkov et al., 2010 and Maki et al., 2011)

The application of water bath method for teat ultrasonography increases the acoustic impedance difference between the teat wall and the surrounding medium. The presence of milk in the teat sinus acted similarly as a window of acoustic impedance for imaging the deeper structures and far wall of the teat. Similar findings were mentioned by (Cartee et al., 1986, Bruckmaier \& Blum, 1992, Rambabu et al., 2008 and Szencziova \& Strapak, 2012). Physiological teat canal sonograms were presented as a thin, white, hyperechoic line circumscribed on each side by parallel hypo- to anechoic bands as mentioned by (Franz et al., 2001).

In subclinical mastitis, the teat canal and sinus showed irregular contour, the three layers of teat wall couldn't be clearly demarcated and the papillary duct and rosette of Furstenberg showed an overlapped pattern with clarity image of udder parenchyma and gland sinus. This could be explained by slight inflammation of these structures. This is in agreement with the results mentioned by (Dinc et al., 2000).

Egypt. J. Vet. Sci. Vol. 44 (2013) 
It was noticed that the echogenicity of milk alveoli in buffaloes suffered subclinical mastitis increased after milking. This is due to the concentration of the somatic cells in the residue of milk after milking.

Ultrasound examination of clinical mastitis showed various images according to the causative agent. In the present study, ultrasound examination of mastitis caused by pyogenic bacteria showed diffuse hypoechoic fluid inside the milk alveoli due to formation of pus. Although, in case of mastitic buffaloes caused by Staph. aureus and Candida spp., the milk alveoli filled with hypoechoic fluid with suspededhyperechoic flakes representing the mycotic hyphae.. Histopathologically, (Thompson et al., 1978) recorded similar finding in udder with mycotic mastitis.

The properties of each udder abscess (concentration of pus and formation of the abscess wall) could be evaluated by ultrasonography. In several cases, clinically non-palpable abscesses due to their small-sized or deep localization were able to be visualized by ultrasound. It was noticed that the parenchymatous abscesses caused by Staph. aureus were less echogenic than that caused by $C$. pyogen. This could be explained by the caseated nature of pus formed by $C$. pyogen.

Udder fibrosis and atrophy appeared ultrasonographically as hyperechoic cordial bands representing the fibrous tissues that replacing the glandular tissues whereas, the other normal quarters appeared as homogenous and hyperechoic with anechoic alveoli. This is in agreement with (Rambabu et al., 2008 ).

\section{Conclusion}

Ultrasonography gives additional information on the status of the udder and teat that help in decision of culling and replacement infected animals or treatments. All forms of mastitis require microbiological confirmation for final diagnosis. Periodic examination for detection new cases of mastitis is recommended.

\section{Acknowledgment}

Sincere appreciation is extended to Dr. Mohamed Zanhom and Dr. HithamBarbery in Ultrasonography Department in Animal Reproduction Research Institute, for their grateful advice and support in this work.

\section{References}

Andrews, A.H., Blowey, R.W., Boyd, W. and Edy, R.G. (2004) "Bovine Medicine. Diseases and Husbandry of Cattle", $2^{\text {nd }}$ ed., Wiley-Blackwell, pp. 358-360.

Bruckmaier, R.M. and Blum, J.W. (1992) B-mode ultrasonography of mammary glands of cows, goats and sheep during a- and b-adrenergic agonist and oxytocin administration, J. Dairy Res., 59, 151-159. 
Cartee, R.E., Ibrahim, A.K. and Mclear, Y.D. (1986) B-mode ultrasonography of the bovine udder and teat. J. Am. Vet. Med. Ass., 188, 1284-1287.

Carter G. and Cole J.R. (1990) "Diagnostic Procedures in Veterinary Bacteriology and Mycology", $5^{\text {th }}$ ed., Academic press. Inc., pp. 469-478.

Djabri, B., Bareille, N., Beaudeau, F. and Seegers, H. (2002) Quarter milk somatic cell count in infected dairy cows: a meta-analysis. Vet. Res., 33 (4), 335-57.

Dinc, D.A., Sendag, S. and Aydin, I. (2000) Diagnosis of teat stenosis in dairy cattle by real-time ultrasonography. Veterinary Record., 147, 270-272.

Fasulkov, I., Georgiev, P.I., Antonov, L. and AtanaSov, S. (2010) B-mode ultrasonography of mammary glands in goats during the lactation period. Bulg. J. Vet. Med., 13, 245-251.

Franz, S., Flock, M., Hofmann R., and Parisot, M. (2009) Ultrasonography of the bovine udder and teat. Veterinary Clinic of North America, Food Animal Practice, 25 669-685.

Franz, S., Hofmann, M., Baumgartner, W., Windischbauer, G., Suchy A., and Bauder B. (2001) Ultrasonography of the bovine teat canal in cows and sheep. Vet. Res., 149, 109-112.

Gungor, O., Pancarci S.M. and Kara A. (2005) Examination of equine udder and teat by B-mode ultrasonography. Kafkas Universitesi Veteriner Fakültesi Dergisi., 11, $107-111$.

Hoquem, N., Jiwary, R., Maiti, S.K., Singh, G.R., Gupta, P. and Kumar, N. (2004) Ultrasonographyof bovine udder and teat. In: Proceeding of XI Annual Congress of Indian association of advancement for Veterinary Research (IAAVR), 134-139.

Jai, W, Lee, S.N., Obrien, A., Juidry, J., Max, K.A. and Shafar, W.A. (2005) Effect of trivalent vaccine against Staph. aureus mastitis lymphocytes subpopulation antibody production and neutrophile phagocytosis. Canadian J. Vet. Res., 69, 11-18.

Karyak, O.G., Safi S. Rahimi and, Bolourchi, M. (2011) Study of the relationship between oxidative stress and subclinical mastitis in dairy cattle. Iranian J. Vet. Res. Shiraz University., 12 (4), 350- 353.

Maki N., Tetsuya Y., Sabry E., Masafumi M., Hidefumi F., Jun, Y., Kazuro M. (2001) Ultrasound Imaging of Mammary Glands in Dairy Heifers at Different Stages of Growth. Vet. Med. Sci., 73 (1), 19-24.

National Mastitis Council (NMC) (1999) Laboratory handbook on bovine mastitis. Madson, 145-147.

National Mastitis Council (NMC) (2004) Bovine mastitis pathogen and trends in resistence to antimicrobial drugs. NMC research committee report. Proceeding of $43^{\text {rd }}$ annual meeting of NMC, Charlatte, U.S.A., 400-414.

Egypt. J. Vet. Sci. Vol. 44 (2013) 
National Mastitis Council (NMC) (2011) Guideline on normal and abnormal milk based on SCC\& Signs of clinical mastitis, Medison, U.S.A., 3-4.

National Mastitis Council (NMC) (2011) $3^{\text {rd }}$ International Symposium on Mastitis and Milk Quality Proceedings, 38-42

Rambabu, K., Makkena, S., Suresh, R.V., Kumar, R. and Rao, T.S. (2008) Ultrasonography of the udder and teat in buffaloes: A comparison of four methods. Buffalo Bulletin, 27, 269-273.

Reneau, J.K. (1986) Effective use of dairy herd improvement somatic cell counts in mastitis control. Journal of Dairy Science, 69, 1708-1720.

Riekerink, R.G., Barkema, H., Veenstra, W., Berg, .F.E., Stryhn, H., and Zadoks, R. (2007) Somatic cell count during and between milking. Journal of Dairy Science, 90, 3733-3741.

Santos, D., Vicente, W., Canola, J. and Lega, E. (2004) B-mode ultrasonography in cows during lactation to evaluate the teat anatomy using four different techniques. Braz. J. Vet. Res. and Anim. Sci., 41, 349-354.

Seker, I., Risvanli, A., Yuksel, M., Saat, N. and Ozmen, O. (2009) Relationship between California Mastitis Test score and ultrasonographic teat measurements in dairy cows. Australian Veterinary Journal, 87 (12), 480-483.

Schalm, O.W. and Noorlander, D.O. (1957) Experiments and observations leading to development of California mastitis test. J. Amer. Vet. Med. Assoc., 130, 199-201.

Sharma, N., Singh, K. and Bhadwal, M.S. (2011) Relationship of Somatic Cell Count and Mastitis. Asian-Aust. J. Anim. Sci., 24 (3), 429 - 438.

Szencziova, I., and Strapak, P. (2012) Ultrasonography of the udder and teat in cattle, perspective measuring technique. Slovak J. Anim. Sci., 45 (3), 96-104.

Thompson, K., Di Menna, M.E., Carter, M.E. and Carman, M.G. (1978) Mycotic mastitis in two cows. New Zealand Veterinary Journal, 26 (7), 176-177.

(Received 29/12/2013; accepted 20/9/2015) 


\section{الصوخيصة التهاب الضرع في الجاموس بالفحص المعملي والموجات}

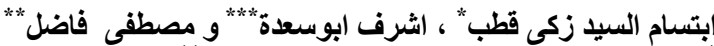

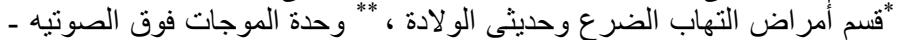

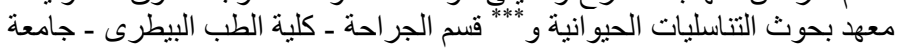

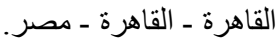

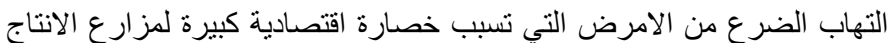

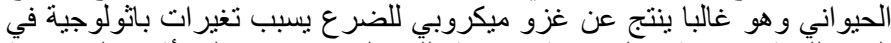

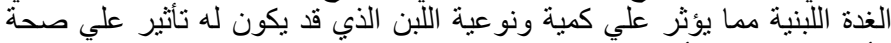

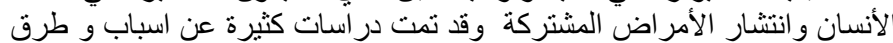

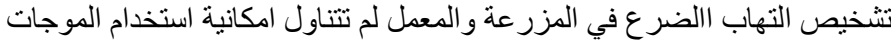

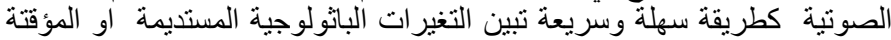

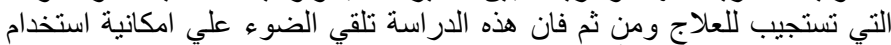

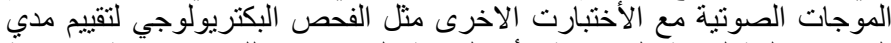

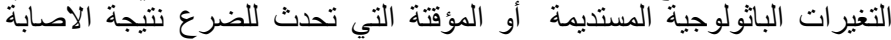

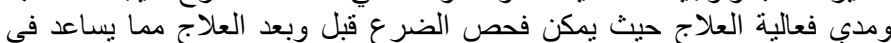
بر امج الأحلال و الاستبدال علي اسس علمية صحيحة .

تمت هذه الدراسة علي 00 من الجاموس الحلاب منها هب مص مصابة بالتهاب

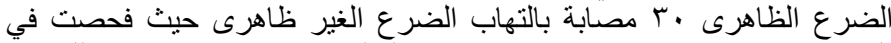

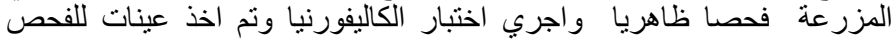

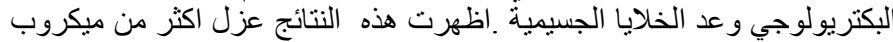

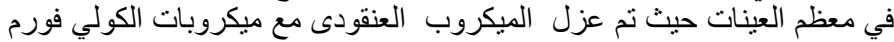

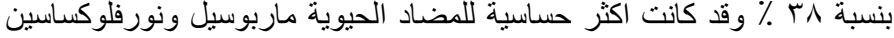

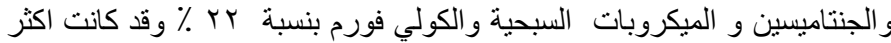

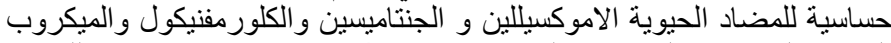

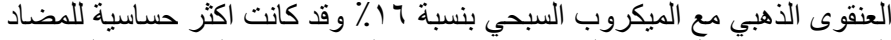

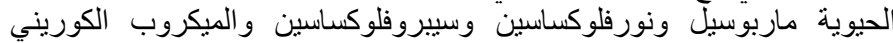

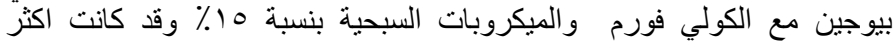

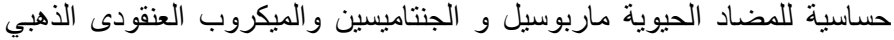

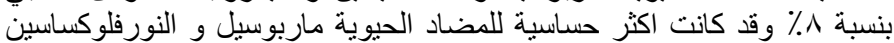

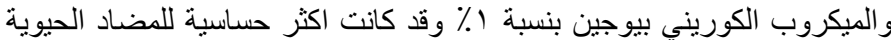

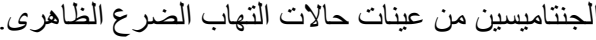

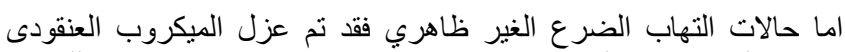

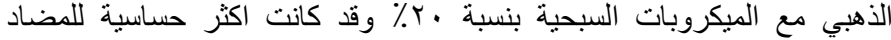

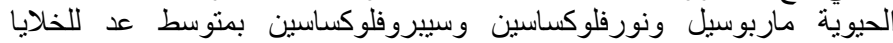

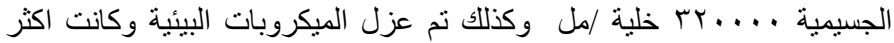

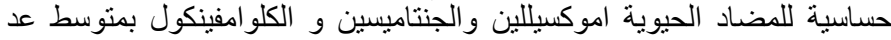

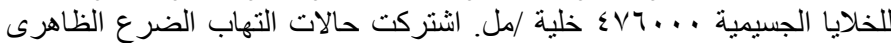

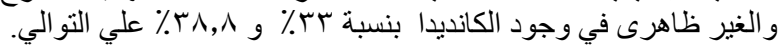

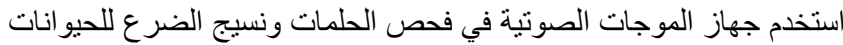

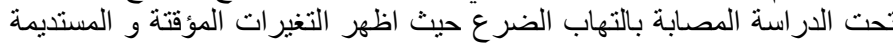
التي حدثت بالانسجة مما ساعد علي اتخاذ القرار بالعلاج او الاستبعاد .

Egypt. J. Vet. Sci. Vol. 44 (2013) 